\title{
The Impact of Rhymes and Songs in the Teaching and Learning of Numeracy in Kindergarten
}

\author{
Otchere-Larbi E.K ${ }^{1} \quad$ Amoah, K.J..$^{*}$ \\ Department of Mathematics and ICT, Presbyterian Women's College of Education, Aburi, Ghana
}

\begin{abstract}
The purpose of this study was to determine the impact of the use of Rhymes and songs in the teaching and learning of numeracy in Kindergarten. The study was a descriptive study in which a survey research design was adopted. Two municipalities in the Eastern Region of Ghana were randomly selected for the study. Simple random sampling was used to sample thirty female Kindergarten teachers from ten Kindergarten schools in both municipalities. Research instrument used was teacher's questionnaire in collecting the data for the study. Findings showed that about $70 \%$ of the Kindergarten teachers use Rhymes and songs in all aspects of their numeracy lesson delivery and as such it created a positive impact on children's learning of numeracy.
\end{abstract}

Keywords: Rhymes, Songs, Numeracy, Kindergarten, Kindergartners

DOI: $10.7176 / \mathrm{JEP} / 11-20-14$

Publication date:July $31^{\text {st }} 2020$

\section{Introduction}

Numeracy is the knowledge, skills, behaviours and dispositions that kindergartners need in order to use mathematics in a wide range of situations. It involves recognising and understanding the role of mathematics in the world and having the dispositions and capacities to use mathematical knowledge and skills purposefully (Moss, O’Mara, and McCandless, 2017). Understanding numbers is an important skill that kindergartners need to master. Children encounter and observe various concepts of mathematics from infancy, such as quantity comparison and pattern recognition (Charlesworth, 2015). Once children reach pre-school age, rhymes and songs are used in teaching them numbers in a fun and interactive way. This makes kindergartners encounter mathematics very early in their lives as they interact with their immediate environment. These encounters usually build in kindergartners great enthusiasm and curiosity (Engel, 2015).

Mathematics as one of the core subjects has been a major problem for kindergartners and even those at the higher levels of education in Ghana (Akyeampong, Lussier, Pryor \& Westbrook, 2013). Learning of numeracy in kindergarten is a basic requirement for number work, so it needs to be taught well in the early stages to improve as children go higher in education. Mathematics at Kindergarten level focuses on sustaining these attributes. Teachers can only get children to learn gradually and develop understanding when mathematics lessons are made enjoyable and interesting through the use of practical activities. This helps children to gain mathematical experiences when they are involved in a wide range of activities (Hämmerle, 2018; National Council for Curriculum and Assessment National Council for Curriculum and Assessment (NaCCA), Ministry of Education, 2019), curriculum for Kindergarten 1 and 2). Participatory activities, play-based and child-centred experiences when established in the classroom enables learners reflect on their experiences, collaborate and interact with other peers and adults engaging actively and connecting what they are learning to their lives daily. Learning then becomes functional, with the use of real-life experiences to help the child apply lessons learnt in their daily lives. Integrated approaches and play methods are used alongside inquiry and discovery in delivering the early childhood curriculum. Through play, learners make sense of the world around them and develop an internal process of inquiry that allows them to think critically and creatively about their environment and what they are learning. Play is critical for developing learners' core skills, which are not only foundational for healthy child development, but are also building blocks for success in school, especially in the areas of literacy (NaCCA, 2019). These activities are prescribed to develop competencies in numeracy such as Critical thinking and Problem solving, Creativity and Innovation, Communication and Collaboration and Cultural identity and Global Citizenship. These activities are known as Activity-oriented pedagogy. Activity-oriented pedagogy helps children to encounter mathematical situations in groups or as individuals, children attain a high level of independent thinking, co-operative attitude, tolerance and leadership skills, which are necessary for further learning of mathematics (NaCCA, 2019).

\section{Importance of numeracy}

The first few years of a child's life are a time of rapid learning, growth and development. Babies and toddlers can recognise number patterns and shapes. Mathematiics concepts are used to make meaning of their world and link these concepts with their surroundings and everyday activities. For example, when playing, children may sort or choose toys according to size, shape, weight or colour (Moss, O'Mara, and McCandless, 2017).

The teaching of concepts and skills to support numeracy occurs in the mathematics learning area to 
strengthen kindergartners to take part in activities that link their learning in the mathematics classroom within the context of other curriculum areas. As they move through their years of schooling, Kingdergardteners are exposed to mathematical understanding, fluency, creativity, problem solving, reasoning. These capabilities allow students to respond to familiar and unfamiliar situations by employing mathematics to make informed decisions and solve problems efficiently (Moss, O’Mara, and McCandless, 2017).

Whiles children sort, match, pair, order, compare, estimate, measure, count and draw conclusions, through the use of games, rhymes and songs, they will be laying a solid foundation for more exciting encounters with further mathematics in later years. This study seeks to look at the use of rhymes and songs during the teaching and learning of numeracy (mathematical activities) at the kindergarten, its impact on the learning of mathematics by children. As researchers who study children's mathematics development, it is evident that there are five mathematical skills that children should have at the start of kindergarten. Opportunities for learning these skills are everywhere and there are simple, enjoyable activities that can foster these skills (Mononen and Aunio, 2013). This research will create an opportunity for early childhood educators and all stakeholders to experience and appreciate the importance of the use of rhymes and songs in the teaching and learning of numeracy at the kindergarten level. It will also create awareness on type of rhymes and songs to be use in the teaching and learning of different concepts (Pinter, 2017). The main focus of this study was to examine the impact and effect of the use of rhymes and songs on the learning of numeracy in the kindergarten. The study will also aim at finding the reasons why teachers at the kindergarten use rhymes and songs as a tool for teaching numeracy, its influence on pupils' academic performance.

\section{Objectives of the study}

The objectives of the study were to;

1. establish why teachers use rhymes and songs as introduction to numeracy lesson presentation in kindergarten?

2. establish why teachers use rhymes and songs intermittently during numeracy lesson presentation in kindergarten?

3. determine the impact of the use of numeracy related rhymes and songs on kindergarteners?

4. determine the extent to which the use of numeracy related rhymes and songs help kindergarteners learn numeracy?

\section{Review of relevant literature}

Rhyme is a short poem often for children; it is a word that ends with the same sound as another word (Sayakhan \& Bradley, 2019). Nursery rhymes are simple verses often accompanied by a simple tune, used for the entertainment and education of small children which are easy yet amazingly powerful memory technique (Tipper, 2018). Number rhymes can be used to memorize a list of items in order by connecting the pegs with the items you want to remember. With a little bit of practice, learners can memorize any list of items. Ultimately, the memory for the list tends to be a lot stronger than if you had used rote learning.

According to Duedu (2016), Number rhymes and songs familiarize children with number and their sequence; he added that children may be led to learn the sequence of numbers one to ten by teaching them Number Rhymes and songs. The children also have fun when they recite the rhymes and sing the songs whiles they perform actions that go with them.

According to Anna (2014), when children do finger plays such as "think" and "Itsy Bitsy Spider" and act out other rhyme such as "Jack Jumped over a Candlestick", they can even improve muscle strength. Counting songs such as "Five Currant Buns" help to develop a familiarity with number sounds and words in a way that is fun and interesting to a young child. Songs such as "When Goldilocks Went to The House of The Bears" also introduce the concept of scale, size and order. Familiarity with counting songs provides the foundation for crucial numeracy skills and awareness (Lee, 2016; Claire, 2019)

Music activates the language, hearing, and rhythmic motor control centers of the brain all at the same time. Words put to songs are often much easier to remember and brings up the example of the ABCs song, in regard to the fact that once learned, most people will never forget it (Sanal \& Gorsev, 2014; Sheridan, 2015).

\section{Methodology}

The study was a descriptive study in which a survey research design was adopted. Descriptive research is an appropriate choice when the research aim is to identify characteristics, frequencies, trends, correlations, and categories. It is useful when not much is known yet about the topic or problem (Hosseinpour, Yahaya \& Sadullah, 2014; Pietkiewicz \& Smith, 2014; Rosenthal, 2016). The population for the study consisted of all Kindergartens in the Eastern Region of Ghana. The sample however consisted of 30 teachers selected randomly from two municipalities in the Eastern Region. The instrument used for the study was a questionnaire and data obtained was analyzed using a descriptive statistic. 


\section{Results and discussions}

What impact does the use of numeracy related rhymes and songs have on the learning of numeracy in the kindergarten?

Table 1 shows classification of teachers according to qualifications

Table 1: Classification of teachers by qualification

\begin{tabular}{ccc}
\hline Highest Education & $\mathrm{N}$ & Percentage (\%) \\
\hline Cert A & 1 & 3.3 \\
Diploma & 21 & 70.0 \\
1st Degree & 5 & 16.7 \\
Others & 3 & 10.0 \\
\hline Total & 30 & 100.0 \\
\hline
\end{tabular}

From Table 1, twenty-one (21) teachers out of the thirty (30) representing 70\% hold a Diploma in Basic Education whilst five (5) teachers representing 16.7\% were first degree holders in Basic Education. Three (3) teachers have not had any training in education and therefore are regarded as non-professional teachers (Pupil teachers). One (1) teacher representing 3.3\% was a certificate " $\mathrm{A}$ " holder. This indicates that $90 \%$ of the teachers have had some formal training in education whilst $10 \%$ were non-professional teachers.

Table 2 shows teaching experience of KG teachers

Table 2: Teaching experience of KG Teachers

\begin{tabular}{ccccc}
\hline Item & $0-5$ & $6-10$ & over 10 & Total \\
\hline Number of years teaching & 20 & 6 & 4 & 30 \\
Number of years teaching in KG & 25 & 3 & 2 & 30 \\
\hline
\end{tabular}

From Table 2, twenty-five (25) teachers have between 0 to 5 years teaching experience in the KG, three (3) teachers have taught between 6 to 10 years in the KG whilst 2 teachers had more than ten (10) years teaching experience in the $\mathrm{KG}$.

Table 3: Courses teachers offered at the college

\begin{tabular}{ccc}
\hline Course offered at College & N & Percentage (\%) \\
\hline ECE & 5 & 16.7 \\
General & 22 & 73.3 \\
Others & 3 & 10.0 \\
\hline Total & 30 & 100.0
\end{tabular}

Table 3 shows courses offered by KG teachers at the colleges they attended

Table 3 shows that out of the thirty (30) teachers only five (5) representing $16.7 \%$ are trained early childhood educators, whilst 22 were trained as general educators and three (3) had training in other courses. Although twenty-five (25) teachers representing $83.3 \%$ who are teaching in $\mathrm{KG}$ were not trained to teach in $\mathrm{KG}$, 22 representing $73.3 \%$ of the teachers had training in general courses. This implies that majority of the teachers teaching in the $\mathrm{KG}$ were not trained to teach in $\mathrm{KG}$, they did a general course or other courses in college.

Table 4: Use of Rhymes and songs by teachers

Statement
I use rhymes and songs as a strategy to teach
mathematics concepts

b I use rhymes and songs to introduce a Numeracy 25 lessons

c I use rhymes and songs intermittently during 19 Numeracy lessons delivery

d I use rhymes and songs to conclude Numeracy 16 lessons

e I use rhymes and songs to evaluate pupils after 9 Numeracy lesson delivery

Always Sometimes

\begin{tabular}{lccc} 
Always & Sometimes & Never & Total \\
\hline 5 & 20 & 5 & 30 \\
25 & 3 & 2 & 30 \\
19 & 6 & 5 & 30 \\
16 & 11 & 3 & 30 \\
9 & 7 & 14 & 30
\end{tabular}

Table 4 shows teachers' responses on how teachers use rhymes and songs in their Numeracy lessons.

From Table 4, Twenty-five (25) teachers (83.33\%) indicated that they always used rhymes and songs to introduce their numeracy lessons, Twenty (20) teachers $(66.67 \%)$ indicated that they sometimes used Rhymes 
and songs to teach mathematics concept in the KG, Nineteen (19) teachers $(63.33 \%)$ indicated that they use rhymes and songs intermittently during numeracy lessons, Sixteen (16) teachers $(53.33 \%)$ use rhymes and songs to conclude their lessons whilst fourteen (14) teachers $(46.67 \%)$ indicated that they had never used rhymes and songs to evaluate pupils understanding of a mathematics concept.

Table 5: Impact of the use of Rhymes and songs on teaching and learning of Numeracy

a

Rhymes and songs help the teacher in her lesson delivery

Children learn mathematical concept easier by the use of Rhymes and songs by the teacher

d delivery

SA A

$16 \quad 12$

12

15

N $\quad$ D

SD
SD

Rhymes and songs arouse pupils' interest during lesson 16

16

12

1

2

Rhymes and songs enabled pupils to recall facts

18

8

0
numeracy.

From Table 5, sixteen (16) teachers representing 53.33\% strongly agreed that rhymes and songs help the teacher in her lesson delivery whilst twelve (12) teachers representing $40 \%$ also agreed to that Rhymes and songs help them in their lesson delivery. None of the teachers disagree to the fact that Rhymes and songs help teachers in their Numeracy lesson delivery. In all, twenty-eight (28) teachers (93.33\%) strongly agreed or agreed that children learn mathematical concepts easier when Rhymes and songs are used in teaching the concept, furthermore 16 teachers (53.33\%) strongly agree, 12 teachers (40\%) agree and only 2 teachers remain neutral to the fact that the use of Rhymes and songs arouse pupils interest during lessons.

\section{Discussions}

Children love to hear, sing and say rhymes and songs. Numeracy related rhymes and songs or counting rhymes and songs can be used as an introduction to basic mathematics concept such as number names, counting objects and number sequence. Rhymes such as "one-two buckle my shoes" help children in counting as well as know the number names in order. This study is in consistent with the study of Conesa \& Rubio, (2015).

Rhymes and songs can be used to introduce or conclude a numeracy lesson and also it can be used intermittently during a lesson delivery. This intent arouses children's interest, making them active and help to sustain their attention throughout the lesson. The loss of children's home language might also result in the disruption of family communication patterns. In the early stages of school, most reading tasks are performed by listening and as a result, children develop strong listening skills and tend to hold on to those skills even in the later stages of schooling, this implies that Rhymes and songs help children at early stage to develop listening and speaking skills.

Children at this stage are very good at imitating though they may not understand what someone does. Children who recite numeracy related rhymes and songs improve their imitation skills which will help them to relate mathematics learnt to their everyday life. Children learn better in a lively and enjoyable atmosphere. The attitude of the teacher reflects the interest and the desire of children to work, so teachers should perform actions with the children when reciting numeracy related Rhymes and songs make learning of numeracy meaningful to the child and devoid of boredoms (Adu \& Frimpong, 2018).

The study revealed that Rhymes and songs should be used so that children can acquire the age-appropriate vocabulary and skills needed for learning mathematics, while staying engaged and having fun. Rhymes and songs will lead kindergartners to build a strong foundation in;

\section{- Counting skills}

Children can demonstrate simple counting skills in kindergarten. These skills include counting to 20; ordering number cards; identifying without counting how many items are in a small set; and understanding that quantity does not change regardless of how a set of items is arranged. Children can also learn cardinality. That means they should understand that the last item counted represents the number of items in the set.

- Games such as Ladders will be cooperative and fun for building counting skills.

Children can identify the number on a die when they take their turn on die games and count aloud when they move their piece. Active games that involve counting aloud - like jumping and clapping games also foster these skills.

\section{- Operations}

Kindergartners can be led to solve simple addition and subtraction problems using objects. During play, children can use toys and help them count how many buildings they have." Songs and rhymes that include counting up or counting down in twos or threes or fours can also be useful for teaching early addition and subtraction. 


\section{- Numbers}

Children can count the number "ten" as a way of emphasizing in base 10. During play, Children will talk about how many toys they can buy with GH $\mathbb{C} 10$.

- Measurement

Kindergartners can sort objects by their features such as shapes, color and size or identify the feature by which objects have been sorted and order objects by some measurable features such as from bigger to smaller bringing to bear information on Measurement and data. Children can begin experimenting with measurement using spoons or cups. Children can sort utensils, laundry or toys as they put them away. Card and dice games are helpful for talking about number magnitude. Additionally, kindergartners should be able to compare objects and use language like more than or less than, longer or shorter, and heavier or lighter.

\section{- Geometry}

Early geometry skills include naming and identifying shapes like circles, squares and triangles. Children also need to realize that shapes of different sizes, orientations and dimensions are similar. Children should be able to recognize that a circle is like a sphere and use informal names like "box" and "ball" to identify threedimensional objects. Children's attention can be drawn to shapes found in the environment. On a walk, it can be pointed out that wheels are circles and then have children find other circles in the environment. Children can identify simple and more complex shapes. Puzzles, blocks and Legos are another great way to help build early spatial skills (Whyte and Bull, 2008; Andrews and Sayers, 2015).

\section{Conclusion}

In conclusion, the focus of development of numeracy concepts and skills should be on providing opportunities for children to recognize, use and apply numeracy concepts and skills meaningfully in their daily experiences by engaging in numeracy related rhymes and songs. The provision of numeracy experiences should be built on children's prior knowledge with emphasis on learning from the manipulation of concrete materials. Through the use of numeracy related rhymes, songs, manipulatives, pictures and symbols, children will identify the relationships between sets of things to be matched, sorted, compared, ordered, made into patterns and counted. They will also develop their understanding of basic shapes and simple spatial concepts.

\section{References}

Adu, J., \& Frimpong, S. O., 2018, Grooming early childhood children: the role of songs and lyrics and rhymes. IFE PsychologIA: An International Journal, 26(1), 182-192.

Andrews, P. and Sayers, J., 2015, Identifying opportunities for grade one children to acquire foundational number sense: developing a framework for cross cultural classroom analyses. Early Childhood Education Journal, 43(4), pp.257-267.

Anna G., 2014, Why do kids need nursery rhymes? (10 reasons!). Retrieved from https://www.themeasuredmom.com/10-reasons-why-kids-need-to-know-nursery-rhymes

Akyeampong, K., Lussier, K., Pryor, J., \& Westbrook, J., 2013, Improving teaching and learning of basic maths and reading in Africa: Does teacher preparation count?. International journal of educational development, $33(3), 272-282$.

Bradley, A., 2017, Book of rhymes: The poetics of hip hop. Civitas Books.

Claire, B., 2019, BLOG: The importance of nursery rhymes in early childhood. Retrieved from www.worldnurseryrhymeweek.com

Conesa, I. M. G., \& Rubio, A. D. J., 2015, The use of rhymes and songs in the Teaching of English in Primary Education. Revista Docencia e Investigación, (25.2), 83-101.

Cook, A., Spinazzola, J., Ford, J., Lanktree, C., Blaustein, M., Cloitre, M., ... \& Mallah, K., 2017, Complex trauma in children and adolescents. Psychiatric annals, 35(5), 390-398.

CRDD- Curriculum Research and Development Division of GES, 2006, Curriculum for kindergarten 1 and 2, Ministry of Education, Science and Sports, Accra

Charlesworth, R., 2015, Math and science for young children. Cengage Learning.

Duedu, C.B., 2016, Teaching Mathematics in Early Childhood Schools, UCC Press, Cape Coast.

Engel, S., 2015, The hungry mind: The origins of curiosity in childhood. Harvard University Press.

Elias, M., 2009,. Use music to develop kids' skills and character. Retrieved from http://www.edutopia.org/music-develop-social-emotional-character

Hämmerle, C., 2018, Enthusiasm, Curiosity and Creative Approaches: In Recognition of Philippe Lejeune's Research. European Journal of Life Writing, 7, CP45-CP50.

Hosseinpour, M., Yahaya, A. S., \& Sadullah, A. F., 2014, Exploring the effects of roadway characteristics on the frequency and severity of head-on crashes: Case studies from Malaysian Federal Roads. Accident Analysis \& Prevention, 62, 209-222.

Kankam, G. and Weiler, J., 2010, A guide to Action Research for Colleges of Education and universities. Read 
wide Publishers, Accra, Ghana.

Lee, J., 2016, Investigating children's abilities to count and make quantitative comparisons. Early Childhood Education Journal, 44(3), 255-262.

Martin. J.L.C, 1994, Mathematics for Teacher Training in Ghana, Distinctive Publishing limited, Accra.

Moss, J., O’Mara, J. and McCandless, T., 2017. School leadership and intercultural understanding: school foyers as situated spaces for doing diversity. International Journal of Inclusive Education, 21(9), pp.956-973.

Mononen, R., \& Aunio, P., 2013, Early mathematical performance in Finnish kindergarten and grade one. LUMAT (2013-2015 Issues), 1(3), 245-261.

Mills, S. W., 2001, The role of musical intelligence in a multiple intelligences focused elementary school. International Journal of Education \& the Arts, 2(4). Retrieved from www.ijea.org/v2n4/index.html

National Association for Education of Young Children, 2010, Early Childhood Inclusion: A joint position statement of the division for Early childhood And the National Association for Education of Young children. Young Exception children, 12(4), 42-47

National Council for Curriculum and Assessment (NaCCA) Ministry of Education, 2019, Kindergarten Curriculum for Preschool (KG 1\&2), September 2019

Pietkiewicz, I., \& Smith, J. A., 2014, A practical guide to using interpretative phenomenological analysis in qualitative research psychology. Psychological journal, 20(1), 7-14.

Pinter, A. , 2017, Teaching young language learners. Oxford University Press.

Prelutsky, J. (Ed.)., 2016, Read-aloud rhymes for the very young. Dragonfly Books.

Rosenthal, M., 2016, Qualitative research methods: Why, when, and how to conduct interviews and focus groups in pharmacy research. Currents in pharmacy teaching and learning, 8(4), 509-516.

Sayakhan, N. I., \& Bradley, D. H., 2019, A Nursery Rhymes as a Vehicle for Teaching English as a Foreign Language. Journal of University of Raparin, 6(1), 44-55.

Schoenfeld, A.H., 2014. Mathematical problem solving. Elsevier.

Shepard, L.A., 1997. The centrality of test use and consequences for test validity. Educational Measurement: Issues and Practice, 16(2), pp.5-24.

Sheridan, M.M., 2015. Singing is Elementary: Teachers' Use of Singing in Three Kodaly-Based Elementary General Music Classrooms (Doctoral dissertation, The Ohio State University).

Sanal, A.M. and Gorsev, S., 2014. Psychological and physiological effects of singing in a choir. Psychology of Music, 42(3), pp.420-429.

Tipper, M., 2018, Instant Recall: Tips and Techniques to Master Your Memory. Watkins Media Limited.

Whyte, J.C. and Bull, R., 2008. Number games, magnitude representation, and basic number skills in preschoolers. Developmental psychology, 44(2), p.588. 